\title{
Nikolina MIŠČEVIĆ* - Attila DUDÁs** \\ The "Environmental Lawsuit" as an Instrument of Preventive Protection of the Constitutional Right to Healthy Environment in the Law of the Republic of Serbia $^{* * *}$
}

\author{
Abstract
}

A lot of attention has been paid to the environment and its protection in Serbian legislation. The right to bealthy environment is guaranteed by the Constitution, and in the last two decades numerous laws have been passed regulating various aspects of the environment in order to ensure its protection. The subject of the paper is the claim to eliminate the danger of damage, stipulated by the Law on Obligations from 1978. From the enactment of the law, this legal institution has been considered as a means suitable for providing preventive environmental protection, which is why it is often called an "environmental lawsuit" in Serbian legal theory.

Keywords: environment, right to a healthy environment, environmental lawsuit, claim to eliminate the danger of damage.

\section{Introduction}

The right to healthy environment in the Republic of Serbia is guaranteed by Art. 74 of the Constitution of the Republic of Serbia, in the part regulating human rights and freedoms. According to the para. 1 of this article, everyone shall have the right to healthy environment and the right to receive timely and full information about the state of environment. This provision stipulates that everyone is obliged to preserve and improve the environment, as well as that everyone, especially the Republic of Serbia and the autonomous province, is responsible for the protection of environment. ${ }^{1}$ The right to a healthy environment is classified in the so-called third generation of human rights, traditionally provided for since the second half of the 20th century, regulating "the environment of people (babitat) and values that are different, but in their entirety have a general, global significance." 2 The theory points out that it indirectly provides additional

Nikolina Miščević - Attila Dudás: The "Environmental Lawsuit" as an Instrument of Preventive Protection of the Constitutional Right to Healthy Environment in the Law of the Republic of Serbia. Journal of Agricultural and Environmental Law ISSN 1788-6171, 2021 Vol. XVI No. 31 pp. 55-69, https://doi.org/10.21029/JAEL.2021.31.55

* Assistant, LL.M., Faculty of Law, University of Novi Sad, e-mail: n.miscevic@pf.uns.ac.rs, ORCID: 0000-0001-9909-1595.

** Associate Professor, PhD, Faculty of Law, University of Novi Sad, e-mail: a.dudas@pf.uns.ac.rs, ORCID: 0000-0001-5804-8013.

*** This study has been written as part of the Ministry of Justice programme aiming to raise the standard of law education.

${ }^{1}$ Art. 74, para. 2 and 3 of the Constitution of the Republic of Serbia.

2 Orlović 2014, 162-163 with further references.

https://doi.org/10.21029/JAEL.2021.31.55 
protection and gives new content to the first basic human right - the right to life. ${ }^{3}$ There is a lasting relationship of interdependence between them, since there is no human life without the environment, that is, the quality of human life depends on the good or bad condition of the environment, and while on the other hand, man can positively and negatively affect the environment. ${ }^{4}$

The field of environmental protection is regulated in more detail by the Law on Environmental Protection (hereinafter: LEP) from 2004, as well as other laws, bylaws and legal acts of the autonomous province and local self-government units. In LEP, the environment is defined as "a set of natural and man-made values whose complex mutual relations constitute the environment, i.e., space and living conditions." This law determines the subjects of environmental protection and the principles on which the environmental protection is based. Art. 9 regulating the principles shows the intention of the legislator to ensure the protection of the environment in accordance with the modern approach in this area of law. Among these principles are the integration principle, which implies the mutually harmonized work of state, autonomous provinces and local self-government units on the improvement and protection of the environment, the principle of prevention and precaution, the 'polluter pays' principle and the principle of sustainable development.

In addition to the LEP, there are laws specifically regulating certain aspects of the environment, such as e.g., Law on the Environmental Impact Assessment (hereinafter: LEIA), ${ }^{5}$ Law on Strategic Environmental Assessment (hereinafter: LSEA), ${ }^{6}$ Law on Waste Management, ${ }^{7}$ Law on the Protection of Air, ${ }^{8}$ Law on the Protection from Noise Pollution in the Environment, ${ }^{9}$ Water Law, ${ }^{10}$ Nature Protection Law, ${ }^{11}$ etc.

There are many different legal instruments which should contribute to the achievement of the goal of environmental protection. Some belong to the field of public law and some to private law. The clear intention of the Serbian legislator to suppress behaviour harming the environment can also be seen from the fact that an entire chapter of the Criminal Code is dedicated to this subject-matter. The chapter regulates criminal liability for environmental pollution, failure to take environmental

\footnotetext{
${ }^{3}$ Ibid, 163.

${ }^{4}$ Ibid, 169.

${ }^{5}$ Law on the Environmental Impact Assessment from 21 December 2004 (Official Gazette No. 135/04 and 36/09).

${ }^{6}$ Law on Strategic Environmental Assessment from 21 December 2004 (Official Gazette, No. 135/04 and 36/09).

${ }^{7}$ Law on Waste Management (Official Gazette, No. 36/2009, 88/2010, 14/2016, 95/2018 other law).

8 Air Protection Law (Official Gazette, No. 36/2009, 10/2013, 26/2021 - other law).

${ }^{9}$ Law on Protection from Noise Pollution in the Environment (Official Gazette No. 36/2009, 88/2010).

${ }_{10}$ Water Law (Official Gazette, No. 30/2010, 93/2012, 101/2016, 95/2018, 95/2018 - other law).

${ }^{11}$ Nature Protection Law (Official Gazette, No. 36/2009, 88/2010, 91/2010, 14/2016, 95/2018

- other law).
} 
protection measures or other acts endangering the environment. ${ }^{12}$ Beside criminal offenses, environmental pollution, or failure to act in accordance with the measures provided by the LEP and other mentioned statutes, may also be qualified as misdemeanour or economic offense. Also, measures of public law include those in the field of administrative law. In addition to these forms of public law protection, environmental protection can also be achieved by legal institutions of private law.

In Serbian legal theory three institutes are most often mentioned in that context: negatory claim from the Law on Foundations of Property Law Relations (hereinafter: LFPLR), ${ }^{13}$ claim for compensation for damages and the claim to eliminate the danger of damage (the so-called environmental lawsuit) from the Law on Obligations (hereinafter: LObl). ${ }^{14}$ The subject of the present paper is the latter, but the negatory claim will also be elaborated in order to compare these two claims in certain aspects.

\section{Property law protection by the negatory claim}

In the domain of civil law, environmental protection has traditionally been achieved within the framework of neighbour relations, i.e., neighbour rights providing protection against impermissible immissions. It is pointed out in the literature that neighbour rights in Serbia are regulated as a legal limitation of the ownership on real estate. ${ }^{15}$ Unlike e.g. the Croatian Law on Ownership and other Real Rights, ${ }^{16}$ or the Law on Property Rights of the Republic of Srpska ${ }^{17}$, which contain a definition of neighbour rights, such definition is not explicitly given in the Serbian LFPLR. Neighbour rights are one of the legal institutions not adequately regulated in the current legislation.

12 Art. 260-277 of Criminal Code (Official Gazette, No. 85/2005, 88/2005 - corrigendum, 107/2005 - corrigendum, 72/2009, 111/2009, 121/2012, 104/2013, 108/2014, 94/2016 and $35 / 2019)$.

${ }^{13}$ Law on Foundations of Property Law Relations (Official Gazette of the Socialistic Federal Republic of Yugoslavia", No. 6/80, 36/90,"Official Gazette of the Federal Republic of Yugoslavia, No. 29/96 and "Official Gazette of the Republic of Serbia", No.115/2005 - other law).

${ }^{14}$ Law on Obligations (Official Gazette of the Federal Republic of Yugoslavia, No. 29/78, 39/85, 45/89 - odluka USJ i 57/89, Official Gazette of the Federal Republic of Yugoslavia, No. 31/93,"Official Gazette of Serbia and Montenegro", No. 1/2003 - Constitutional Charter and "Official Gazette of RS", No. 18/2020)

15 Vučković 2018, 60.

16 According to Art. 100, para. 1 of the Croatian Law on Ownership, neighbour rights represent the powers given by law to the owner of one real estate to, in connection with the exercise of his ownership, demand from the owner of another real estate to do or to refrain from something that he or she, as the owner, could do by law.

17 Art. 66, para. 1 of the Law on Property Rights of the Republic of Srpska ("Official Gazette of RS", No. 124/2008, 3/2009 - corrigendum, 58/2009, 95/2011, 60/2015, 18/2016 CC decision, 107/2019 and 1/2021 - CC decision) stipulates that "the owner of real estate in the exercise of his or her powers from his ownership has the obligation to act carefully towards the owner of another real estate, and who refrains or does in his interest something that is determined by law (neighbour rights). 
Aside from the Art. 5 of the LPFLR, referring to the admissibility of harmful influences in neighbour relations, the rules from the Serbian Civil Code from 1844 are still applicable to these relations on the basis of Art. 4 of the Law on the Invalidity of Legal Regulations Adopted Before April 6 and During Enemy Occupation. ${ }^{18}$

An important neighbour right is the one providing protection against excessive immissions. The term "immission" means harmful influence coming from one real estate to the neighbouring one, making the use of the latter difficult. It is often described by listing examples of harmful influences, such as noise, unpleasant odours, smoke, dust, heat, light, etc. ${ }^{19}$ The Serbian LFPLR does not use the term 'immission', but it determines what is considered an impermissible way of exercising property rights. ${ }^{20}$ Art. 5 stipulates the duty of the owner to "refrain from actions when using real estate and to eliminate the causes coming from his real estate, making the use of another real estate difficult (transmission of smoke, odours, heat, soot, earthquakes, noise, wastewater runoff etc.) beyond the usual measure, in light of the nature and purpose of the real estate and local conditions, or causing significant damage." Par. 2 of this article prohibits also the mentioned disturbances without a special legal basis by using special devices. According to Cvetić, from the wording of Art. 5 of the LFPLR, using the expression 'other real estate', and not 'neighbouring real estate', it can be concluded that protection against immissions exceeds the limits of neighbour rights. ${ }^{21}$ It can be said that this is in line with the need to protect the environment from harmful influences that are continuously increasing due to the modern way of life, technological and industrial development. The Serbian theory points out that these processes endanger material goods and the environment to a greater extent, so the harmful effects arising from them exceed the usual understanding of immission as a harmful influence from one land to the neighbouring one, i.e. as an influence of material nature that can be noticed. ${ }^{22}$ Thus, according to the understanding of these authors, there is a need for a different conceptual definition of immission by including other forms of harmful influences, as a wider space in which these influences can manifest themselves. ${ }^{23}$

Protection against excessive immissions in Serbian law can be achieved by different claims belonging to property law or to the law of obligations. In property law negatory claim and possessory claim can contribute to the protection of the environment, because they serve to stop disturbing the holders of property rights and to prevent further disturbance. ${ }^{24}$ However, in the context of protection against excessive immissions through the legal institutions of property law, Serbian authors regularly mention negatory claim from Art. 42 of the LFPLR. According to this rule, in the case when the disturbance does not consist in the loss of the possession, but is accomplished in another way, the owner, i.e. the presumed owner, may demand from

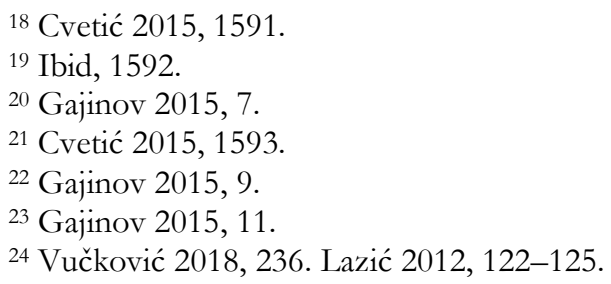


the third person who is unjustifiably disturbing to cease the disturbance. This right of the owner does not become unenforceable by the laps of time. Also, para. 2 of this article stipulates that the owner has the right to claim for the compensation for damages according to the general rules on damages in case the damage is caused to him by the disturbance.

Negatory claim requires the fulfilment of several conditions. First, it is necessary that the third party does not have a legal ground for taking the action which the owner considers disturbance. In addition, the immission must be excessive, meaning that the harmful influences from one real estate on another must be greater than usual at the given locality, taking into consideration the nature and purpose of the real estate. Excessive immissions constitute unlawful disturbance as a condition for protection under Art. 42 of the LFPLR. Therefore, as Knežević points out, illicit immissions are merely a form in which disturbance to other real estate manifests itself, thus the precondition for a negatory claim from Art. 42 of the LFPLR exists. The condition of this claim is that disturbance has actually occurred and it is unlawful. In the case of disturbance by harmful immissions, Art. 5, para. 1 of the LFPLR determines when the immission is considered unlawful. ${ }^{25}$

The means of use of a real estate exceeding the usual extent from Art. 5 of the LFPLR is a legal standard according to which the court in each specific case assesses whether there is an excessive immission. In doing so, the court takes into account whether the real estate from which the immissions originate in the particular case is located in a village or town, in a residential area or industrial zone of the city, what is the purpose of the real estate, the extent of damage caused by immission, whether there is a special regulation stipulating the immission impermissible, etc. ${ }^{26}$ As the detailed regulation of environmental protection for most types of immissions determined environmental standards and established precise limits of tolerance of these influences (e.g. in decibels for noise, or a precise measure of harmful gases in the air), the court in determining whether disturbance exists usually relies on these objective criteria too. ${ }^{27}$

Also, for granting protection against immissions by a negatory claim, it is necessary that the disturbance is permanent. ${ }^{28}$ When it comes to protection against excessive immissions through a negatory claim, in theory, the range of persons who have cause of action is still discussed, ${ }^{29}$ as well as the distribution of the burden of proof in the procedure initiated for the realization of this claim ${ }^{30}$.

\footnotetext{
${ }^{25}$ Knežević 2013, 364. Given the different interpretations of the nature of the claim from Art. 42 of the LPFPLR in Serbian literature, Kneřevic points out that this is a negatory claim as a special subjective right arising from the violation of another, existing subjective right or legally protected interest - in this case the ownership. Knežević 2013, 356-358.

${ }^{26}$ Lazić 2012, 119.; Josipović 2017, 59-60.

${ }^{27}$ Lazić 2012, 119.

${ }^{28}$ Lazić 2012, 124.; Gajinov 2015, 214.

${ }^{29}$ Popov, Nikolić, M. Salma, Cvetić \& Knežević 2017, 89.

${ }^{30}$ Knežević 2013, 353-374.; Cvetić 2015, 1594.
} 
3. Protection of the environment by the so-called environmental lawsuit of the law of obligations

Another means of civil law protection of the environment is the so-called environmental lawsuit from Art. 156 of the LObl. It prescribes that everyone may demand from another the removal of a source of danger threatening to cause considerable damage to him or her or to an unspecified number of persons, as well as to refrain from any activity causing disturbance or danger of loss, should the ensuing disturbance or loss be impossible to prevent by adequate measures.

This rule represents the concretization of the principle of prohibition of causing damage from Art. 16 of the LObl, according to which "everyone shall be bound to refrain from an act which may cause damage to another."

The preventive claim for the removal of the source of danger from Art. 156 of the LObl, as well as the negatory claim, does not have the exclusive function of environmental protection but is intended to protect individuals and legal entities from considerable damage of any kind. However, it has a significant role in the protection against impermissible immissions. By preventing harmful immissions, preventive protection of the environment is provided. Thus, although it primarily serves the protection of private subjective rights, this claim indirectly protects the public interest as well. ${ }^{31}$

This lawsuit shows several advantages over the negatory claim. First, the negatory claim is limited, as a rule, to a neighbouring real estate. Also, the scope of persons who have active or passive legal standing in a dispute initiated by a negatory lawsuit is significantly narrower than the circle of persons who can appear as a plaintiff, i.e., a defendant in a dispute under the so-called environmental lawsuit. As can be seen from para. 1 of this article, everyone has the right to demand the removal of the source of danger. Therefore, the claim holders are not only persons who are threatened by considerable damage, but also all third parties if the occurrence of considerable damage threatens an indefinite circle of persons. ${ }^{32}$ That is why it is also called a popular lawsuit (actio popularis)..$^{33}$ To that extent, the so-called environmental lawsuit differs from the classic civil lawsuit which can be filed only because of the violation of a subjective right a concrete person, or his or her legally protected interest. ${ }^{34}$

\footnotetext{
31 Petrušić 2009, 219; T. Josipović, 53. Josipović in her paper writes about the environmental lawsuit in Croatian law, regulated by Art. 1047 of the Croatian Law on Obligations (Official Gazette of Republic of Croatia No. 35/05, 41/08, 125/11, 78/15, 29/18), which is almost identical to Art. 156 of the LObl that remained in force in Croatia until the enactment of the valid Law on Obligations.

32 Popov, Nikolić, Salma M., Cvetić \& Knežević 2017, 88.

33 Popular lawsuits (actones popularis) in Roman law were established with the aim of protecting a wider interest by private initiative. They could be submitted by any citizen in case he notices that a certain regulation has been violated. Malenica 2007, 402.

${ }^{34}$ Salma M. 2014, 134.
} 
Nikolina Miščević - Attila Dudás

The "Environmental Lawsuit" as an Instrument of Preventive

Protection of the Constitutional Right to Healthy Environment

in the Law of the Republic of Serbia
Journal of Agricultural and

Environmental Law

$31 / 2021$

\subsection{Claims arising from Art. 156 of the LObl}

Art. $156 \mathrm{LObl}$ regulates three different claims: the claim for elimination of the source of danger, claim for prevention of damage or disturbance and the claim for compensation for damages. Par. 1 stipulates that "everyone may demand from another to remove a source of danger from which he or an indefinite circle of persons is threatened with considerable damage, as well as to refrain from an activity which causes disturbance or danger of damage in case that the occurrence of disturbance or damage cannot be prevented by other appropriate measures." In the para. 2 the possibility is provided for the court to order, on the demand of the interested person, certain measures in order to prevent damage or disturbance, or to eliminate the source of danger at the expense of the holder of the source of danger, if he or she him- or herself does not do so.

According to para. 3 and 4 of the Art. 156 of the LObl, if the damage occurs in the performance of an activity undertaken in the interest of the general public for which a permit from a competent authority has been obtained, only compensation for damage exceeding normal limits may be demanded. Besides that, in these cases, socially justifiable measures for the prevention or reduction of damage may be demanded.

\subsubsection{Claim for the removal of the source of danger of damage and for refraining from activities from which the disturbance or danger of damage arises}

This claim serves to protect from considerable damage when its occurrence cannot be prevented in any other way, by taking other measures, but only by cutting it at the root, i.e. by removing the source from which it threatens to arise, or by ceasing of activities threatening of causing damage or disturbance. This claim requires the fulfilment of several conditions regarding the magnitude of the damage, the danger of its occurrence and the source of danger.

(a) Considerable damage - While the condition of a negatory claim is the unlawfulness of the disturbance causing excessive immissions, the condition of a popular claim for elimination of the source of danger of damage from Art. 156 of the LObl is that the damage is "considerable". In other words, it is not enough that any damage threatens, but it must be of a greater relevance.

When speaking about the popular claim or the so-called environmental lawsuit as an instrument of environmental protection, the concept of damage must be determined first. Namely, in Serbian law, damage, in the civil law sense, is the reduction of someone's property, prevention of its increase, as well as inflicting physical pain, mental pain or fear on another. ${ }^{35}$ On the other hand, the LEP uses the term 'environmental pollution' or 'environmental damage' in the context of damage and liability for damage. ${ }^{36}$ Environmental pollution is defined in the introductory provisions of this law as "the introduction of pollutants or energy into the environment, caused either by buman activities or

\footnotetext{
35 Art. 155 LObl.
}

36 Art. 102-108 LEP. 
natural processes, which has or may have adverse effects towards quality of the environment and human bealth. '" $"$ 7

Therefore, in theory, a distinction is made between environmental damage and the classical term of damage in civil law sense. Environmental damage, according to J. Szalma, is a broader term since it sometimes does not consist in diminishing someone else's property or violating someone else's mental or physical integrity. ${ }^{38}$ Environmental damage "is simply not measurable by the criteria of civil law, because it is sometimes enormous, financially inexpressible, and often cannot be tied only to the property of a particular person, even sometimes cannot be treated as public goods, tied to a particular state sovereignty in the classical sense of the word." 39 This author distinguishes environmental damage from environmental damage in a narrow sense, by which he means environmental damage that is economically measurable, i.e. refers to the property of a particular person. ${ }^{40}$ It can be subsumed under the classic civil law concept of damage, and it is characterized by the fact that it occurs as a consequence of an immission. This division in Serbian theory is also made by other authors, but they do not use the term "environmental damage in a narrow sense." These authors make a difference between 'environmental damage' which means damage to the environment and "traditional damage" including damage from polluted environment. ${ }^{41}$ According to Cvetic, environmental damage is a damage to the environment that "does not mean a violation of private interest" at the same time. ${ }^{42}$

In any case the damage must not be insignificant. ${ }^{43}$ The court will evaluate that in each individual case. Some authors proposed guidelines for the assessment whether the extent of the threatening damage justifies this sort of claim. Thus, some point out that this issue should be assessed from the point of view of the party suffering the damage, i.e., who is threatened by the damage. They assert that one should also consider the geographical area where the damage threatens to occur. ${ }^{44}$ In addition, in theory, there are proposals to adopt certain criteria according to which the court in a particular case would assess whether the standard of 'considerable damage' is met or not. According to Josipovic, the court should take into account the type and scope of personal rights, the type of things threatened by damage and their value, the number of persons threatened by damage, the size and purpose of the endangered area, etc. ${ }^{45}$ Brkic proposes the introduction of one general and several special criteria. According to this author, human life and health, as well as balance in nature, can be taken as a general criterion. Therefore, it could be said that a threat of considerable damage exists when there is a danger that the harmful event will result in death or damage to human health or environmental pollution in terms of the provisions of the LEP. ${ }^{46}$ This author points out

\footnotetext{
${ }^{37}$ Art. 3, para. 1, item 11.

${ }^{38}$ Salma J. 2009, 38.

${ }^{39}$ Ibid.

${ }^{40}$ Ibid.

${ }^{41}$ Karanikić Mirić 2007, 465.

${ }^{42}$ Cvetić 2014, 295-296.

${ }^{43}$ Cigoj 1980, 436-437.

${ }^{44}$ Ibid, 437.

${ }^{45}$ Josipović 2017, 69

${ }^{46}$ Brkić 2019, 302
} 
that by applying the term of damage in sense of environmental pollution from the LEP, it is achieved that the extent of damage is not assessed exclusively according to economic criteria, but according to biological ones. This is important considering that certain harmful consequences to the environment could not be economically valued even though they have an exceptional biological value, such as e.g. the extinction of a particular species. ${ }^{47}$ This author, therefore, suggests that when applying Art. 156 of the $\mathrm{LObl}$, in the case when the damage threatens the environment, one should rely on the term of economic damage as understood by the previously mentioned authors, and not from the damage in the classical civil law sense. As special criteria, this author mentions those related to neighbour relations ${ }^{48}$, criteria related to areas where the risk of damage occurs ${ }^{49}$, criteria in case there are rules that precisely determine the limits of permissible influence on environmental elements ${ }^{50}$ and criteria related to the object of protection ${ }^{51}$.

(b) Danger of damage and a high degree of probability that the damage will occur - The domestic theory points out that the mere existence of a danger of damage is not sufficient to grant protection on the basis of this claim. The danger of damage should be "concrete and certain, and not contingent on a completely uncertain future event". 52 There needs to be a high level of probability that the damage will occur if appropriate measures are not taken to prevent it. ${ }^{53}$ Since this is a preventive claim,

\footnotetext{
${ }^{47}$ Ibid.

48 In neighborly relations, there would be a danger of significant damage if the neighbor undertakes certain actions without the necessary attention, that is, with a lower degree of attention than expected from other neighbors in this particular case. Ibid, 303 with further reference.

${ }^{49}$ This criterion implies that the court should take into account the area in which the danger of damage occurs, i.e., whether it is an area in which the activity is carried out, implying an increased danger of the occurrence of harmful consequences, i.e. pollution on scale larger than usual. Also, it is emphasized that this criterion cannot be applied outside the limits of the stated general criterion. Ibid, 304 with further reference.

50 According to this criterion, if the regulations explicitly stipulate the limit to which certain harmful effects are considered permissible, anything exceeding that limit should be considered as considerable damage. Ibid, 305.

51 This author also states that when assessing the extent of damage, the object threatened by damage should be considered, i.e. whether it is life, health, personal property or the environment. Thus, if the damage threatens property, it is taken into account whether it originates from the performance of a certain activity for which a permit has been issued and to which another criterion refers. If the damage threatens health, Brkić emphasizes that one should separate physical or mental pain and fear of impairing health by causing a certain disease. This is because physical, mental pain and fear are of an individual character and their existence, intensity and duration in the same circumstances can vary from person to person. Therefore, the court expert in the procedure cannot assess whether a person would suffer any of these types of non-pecuniary damage and what intensity they would be, i.e. whether the condition of "considerable damage" would be met. On the other hand, if he can determine that there is a risk of injury or illness, this condition should be considered fulfilled. When it comes to the environment, the above general criterion applies. Ibid. 306-307.

52 Šago 2013, 904.

${ }^{53}$ Salma M. 2014, 135.
} 
it is necessary that the damage has not yet occurred, but "that the risk is on a certain path of realization. '54 An example of this is the case of the existence of intense harmful ionizing radiation by which the health consequences have not yet occurred, but it is certain that they will do so if no measures are taken to prevent or reduce the degree of radiation. ${ }^{55}$

(c) Causal link between the source of danger or activity and the potential damage - As one of the conditions to achieve legal protection by this claim, some Serbian authors name also the causal link between the source of danger and the potential damage. ${ }^{56}$

\subsubsection{Claim for taking measures to prevent disturbance or damage}

The possibility of filing this sort of claim is not so clearly stipulated in Art. 156, para. 1 of the LObl, as the claim for elimination of the source of danger or refraining from the activity from which the disturbance or danger of damage arises, but follows the logic by which the former is regulated. Namely, according to this provision, the claim for the elimination of a source of danger depends on the possibility of preventing the occurrence of damage by taking appropriate measures. This means that a person who assesses that he or she or an indefinite number of persons is threatened with considerable damage from a certain source of danger or due to the performance of a certain activity of another person may first demand prevention of the occurrence of the given damage in another way than by removing that source. ${ }^{57}$ These measures differ, depending on what the source of danger is. It can be e.g. installation of appropriate filters at the factory plant in order to prevent the release of harmful gases into the air, installation of water purifier in order to prevent the spillage of toxic substances into the river, installation of sound insulation, etc.

However, vindicating these demands in court proceedings by the so-called environmental lawsuits are not without difficulties. Before filing a lawsuit, it is necessary to identify the source of the danger, and clearly determine the specific measures that need to be taken and justified in order to eliminate the danger of damage. This requires appropriate knowledge, which, as a rule, a plaintiff does not have, and, hence, consulting an expert of the appropriate expertise already in the phase of preparation of the lawsuit and before initiating the litigation. The justification of these measures and their suitability for the prevention of damage or disturbance should be proven in the proceedings, which also implies the participation of experts, and thus imposing significant costs on the plaintiff. ${ }^{58}$

\footnotetext{
54 Salma J. 2009, 42.

${ }_{55}^{5}$ Salma J. 2009, 42; Salma M. 2014, 140.

${ }^{56}$ Salma J. \& Nikolić 2009, 189; Salma M. 2014, 135.

${ }^{57}$ Dudás 2015, 33.

${ }^{58}$ Josipović 2017, 65-66. and 70.; Maganić 2017, 39.
} 
Nikolina Miščević - Attila Dudás

The "Environmental Lawsuit" as an Instrument of Preventive

Protection of the Constitutional Right to Healthy Environment in the Law of the Republic of Serbia
Journal of Agricultural and

Environmental Law

$31 / 2021$

\subsubsection{Claim for compensation for damages}

Par. 3. and 4. of Art. 156 of the LObl regulate the case when the damage occurs due to the performance of an activity undertaken in the interest of the general public for which a competent authority has given a permit. According to these rules, only compensation for damages can be claimed in such circumstances. At the same time, the injured party cannot claim compensation for the entire damage he or she suffers, but only for the damage 'exceeding normal limits'. Since it is necessary for the damage to have already occurred in order to enable the plaintiff to file this claim, it does not have a preventive character, unlike the previously mentioned ones. Since the risk of damage in this case has already been realized, and it is possible to identify the person who suffers the harmful consequences of performing this generally beneficial activity, only to the injured party has active standing in the litigation. In that sense, this is not a socalled popular lawsuit, as it is the case with the claim to implement measures for the prevention of damage or disturbance, or a claim to eliminate the source of danger of damage or to refrain from activities resulting in disturbance.

Therefore, when it comes to a generally beneficial activity the performance of which has been permitted by a competent authority, it is not possible to demand forbearance from performing this activity, but only compensation for excessive damage caused to a certain person. This rule is an manifestation of the idea of the so-called socialization of risks, according to which all citizens benefit from development, and in that sense, everyone should bear the environmental consequences within certain limits. ${ }^{59}$ However, preventive protection in the case of performing generally beneficial activity is sought to be achieved by administrative measures contained in LEP, LEIA, LSEA and other regulations establishing limit values of allowed immissions, conditions for obtaining permits and licenses for work, etc. ${ }^{60}$

However, in addition to compensation for excessive damage, the implementation of socially justified measures for the prevention of damage or its reduction may also be requested. By this way, the lawsuit from Art. 156, para. 3 and 4 of the LObl still can have preventive effect. In that case, it is also necessary to state in the lawsuit the specific measures whose performance is requested.

\section{The right to a healthy environment in the case law of the Constitutional Court of the Republic of Serbia}

In Serbian law constitutional appeal is a special legal remedy providing protection in the case of violation of human or minority rights guaranteed by the Constitution. In accordance with Art. 170 of the Constitution of the Republic of Serbia, a constitutional appeal may be lodged against individual acts or actions performed by state bodies or organisations exercising delegated public powers infringing or denying human or minority rights and freedoms guaranteed by the Constitution, if other legal remedies for their protection have already been exhausted or they are not envisaged at

${ }^{59}$ Salma M. 2014, 139.

${ }^{60}$ Vučković 2018, 262. 
all. In the case law of the Constitutional Court there are not too many cases of constitutional appeals asserting violation of the right to a healthy environment. ${ }^{61}$ Among them, only one ended with the decision by which the Constitutional Court upheld the constitutional appeal and established the violation of the right to a healthy environment from the Art. 74 of the Constitution. ${ }^{62}$ In this case, the complainants claimed a violation of the right to a fair trial under Art. 32, para. 1 in connection with the right to a healthy environment under Art. 74 of the Constitution. Namely, the complainants asserted that the Court of Appeals in Novi Sad arbitrarily applied the substantive law when deciding on the claim for the elimination of the transmission line pole producing harmful radiation from their yard, and by that violated their right to a fair trial. The civil procedure, which ended with the judgement of the Court of Appeals in Novi Sad ${ }^{63}$, against which a constitutional appeal was filed, was initiated by a lawsuit in the Municipal Court in Bačka Palanka against the Public Company Electric Network of Serbia. In addition to compensation for non-pecuniary damage due to fear and stress, the plaintiffs demanded the elimination of the transmission line pole that the predecessor of the defendant company placed in their yard or the payment of a certain amount of money which would grant the defendant the right to use the plaintiffs' land and facilities. During the litigation, expertise of electrical, geodetic, and oncological experts, as well as experts of the 'Vinča Institute of Nuclear Sciences' and the Public Company 'Nuclear Facilities of Serbia' were submitted.

The Constitutional Court established the violation of the right in the manner of evaluation of the expert findings and opinion by the Court of Appeals. The expert's finding of the 'Vinča Institute of Nuclear Sciences' was accepted only in the part stating that the measured maximum values are many times less than the reference values in comparison with the guidelines of the International Commission for Protection of Non-Ionizing Radiation and the Rulebook on Exposure Limits to Non-Ionizing Radiation. On the other hand, the Court of Appeals assessed the part related to the proposed measures - relocation of the transmission line pole or eviction of the plaintiffs' household as a non-binding recommendation because only the laws of the Republic of Serbia can be applied to a specific case, and not Russian norms referred to by the experts.

In connection to the claim for removal of the transmission line pole pursuant to Art. 156 of the LObl, the Court of Appeals in Novi Sad considered that the claim was not founded since the transmission line pole does not represent a source of danger from which considerable damage threatens. Also, this court referred to para. 3 of this article, pointing out that even if it were determined that the plaintiffs suffered damage, the request for removal of the pillar would not be justified because it is a generally

\footnotetext{
${ }^{61}$ Decisions od the Constitutional Court No. Už-1198/2008 from 3 March 2011, Už-1424/2008 from 31 March 2011, Už-2945/2013 from 23 December 2015. and Už-7702/2013 from 7 December 2017.

${ }^{62}$ Decisions od the Constitutional Court No. Už-7702/2013 from 07.12.2017. Bulletin of the Constitutional Court for 2017, Belgrade 2019, 612-629.

${ }^{63}$ Decision of the Court of Apeal in Novi Sad No. Gž. 3677/12 from 20 June 2013.
} 
beneficial activity, and the plaintiffs could only claim damages exceeding normal limits, which they did not do in the lawsuit.

In relation to this position of the Court of Appeals, the Constitutional Court pointed out that Art. 156, para. 4 stipulating that in the case referred to in para. 3, one may also demand the implementation of socially justified measures to prevent damage or for its reduction and noted that the Court of Appeals did not even refer to the given provision in its reasoning. Since the Court of Appeals found the claim for non-pecuniary damage justified, emphasising that the plaintiffs suffered this damage simply because they knew that radiation could cause a danger to their health or life, the Constitutional Court wondered why these circumstances were not taken into account properly when assessing that the given transmission line pole does not represent a source of danger. ${ }^{64}$

The Constitutional Court concluded that the Court of Appeals in Novi Sad, in reasoning of the judgement, failed to establish and take into consideration all relevant aspects of this case and to take a stand in relation to them. According to the Constitutional Court, "failure to consider issues that are crucial for assessing the merits of a claim in the context of the right to a healthy environment has led to a violation of the right to a reasoned court decision, as an element of the right to a fair trial from the Art. 32, para. 1 of the Constitution, in connection with the right to a healthy environment from Art. 74 of the Constitution". ${ }^{65}$

\section{Conclusion}

The right to healthy environment is guaranteed by Art. 74 of the Constitution of the Republic of Serbia. In order to protect it, numerous laws have been passed which regulate various elements and aspects of the environment. As the protection of the environment requires a comprehensive approach, these laws contain measures of criminal law, rules on misdemeanour or administrative law which should ensure the achievement of this goal. In addition to them, certain legal institutions of civil law also contribute to the protection of the environment, such as the compensation for damages, a negatory claim and a claim to eliminate the danger of damage (the so-called environmental lawsuit). The paper analyzes the latter: the claim from Art. 156 of the LObl. The authors point out that this article actually contains three different claims: a claim to remove the source of danger, a claim to prevent damage or disturbance, and a claim for compensation for damage caused by performing generally beneficial activities. The main advantage of this legal institution is its preventive character, i.e., the possibility to request from the liable person to take appropriate measures in order to prevent the occurrence of damage or disturbance, even before the damage arises from the holder of the source of danger, i.e., the performer of the activity from which the disturbance or the damage threatens. If this cannot be achieved by appropriate measures, one can demand the elimination of the source of the danger, i.e., the cessation of performing the activity.

${ }^{64}$ Ibid. 612-629.

${ }^{65}$ Ibid. 629. 
An additional advantage of the claim, that is, the environmental lawsuit from Art. 156 of the LObl, is that everyone can file it, and not only the person who is directly threatened with the damage (popular lawsuit). When the threat of damage stems from a generally beneficial activity for which the permission of a competent authority has been obtained, it is not possible to demand the termination of the activity, but only compensation for the damage in the extent exceeding normal limits. Therefore, this claim does not have a preventive character and cannot be requested by everyone, but only by the person who suffered the damage. However, even in this case, there is a claim for implementing socially justified measures for the prevention of the occurrence of damage or its reduction, which has a preventive character.

In this paper the conditions of these claims, and certain facts that may hinder their implementation in the civil procedure were analysed in order to encourage their application in the future.

At the end of the paper, authors presented the decision of the Constitutional Court of the Republic of Serbia on the constitutional appeal due to the violation of the right to a fair trial in connection with the right to a healthy environment in a civil procedure regarding the claim to eliminate the source of danger from damage from Art. 156 of the LObl. 
Nikolina Miščević - Attila Dudás

The "Environmental Lawsuit" as an Instrument of Preventive

Protection of the Constitutional Right to Healthy Environment in the Law of the Republic of Serbia
Journal of Agricultural and

Environmental Law

$31 / 2021$

\section{Bibliography}

1. Brkić M (2019) Pojam znatnije štete u preventivnoj zaštiti životne sredine, Glasnik Advokatske komore Vojvodine, 3/2019, pp. 294-310.

2. Cigoj S in Blagojević B, Krulj V (1980) Komentar Zakona o obligacionim odnosima, Beograd.

3. Cvetić R (2014) Održivi razvoj i ekološka šteta, Zbornik radova Pravnog fakulteta u Nišu, No. 68, pp. 291-302.

4. Cvetić R (2015) Značaj negatorne tužbe za zaštitu životne sredine, Zbornik radova Pravnog fakulteta u Novom Sadu, 4(49), pp. 1583-1595.

5. Dudás A (2015) Környezetvédelmi polgári jogi felelősség a szerb jogban, in: Sápi E (ed.) Decem anni in Europaea Unione III, Miskolci Egyetemi Kiadó, Miskolc, pp. 27-42.

6. Gajinov T (2015) Gradanskopravna odgovornost za imisije, doctoral thesis, Novi Sad.

7. Josipović T (2017) Građanskopravna zaštita od štetnih imisija, in: Barbić J (ed.) Građanskopravna zaštita okoliša, Zagreb, pp. 53-84.

8. Lazić M (2012) Imisije i građanskopravna zaštita, Pravna riječ, 32(9), pp. 113-129.

9. Karanikić Mirić M (2007) Odgovornost za zagađenje životne sredine, Pravni život, 9(59), pp. 455-479.

10. Knežević M (2013) Teret dokazivanja nedozvoljenosti imisija kao pretpostavke negatornog zahteva, Zbornik Pravnog fakulteta u Novom Sadu, 4(47), pp. 357-374.

11. Maganić A (2017) Procesnopravni aspekti građanskopravne zaštite okoliša, in: Barbić J (ed.) Građanskopravna zaštita okoliša, Zagreb, pp. 21-52.

12. Malenica A (2017) Rimsko pravo, Novi Sad

13. Orlović S (2014) Pravo na život u Ustavu, Zbornik radova Pravnog fakulteta u Novom Sadu, 4(48), pp. 161-175.

14. Petrušić N (2009) Zaštita životne sredine u građanskom sudskom postupku, in: Nikolić D (ed.) Osnove prava životne sredine, pp. 217-244.

15. Popov D, Nikolić D, Salma M, Cvetić R \& Knežević M (2017) "Der Umweltschutz und bürgerliches Recht - materiell- und prozessualrechtliche Aspekte", Legal Aspects of Biomedicine and Environmental Protection, Novi Sad, pp. 81-93.

16. Salma J \& Nikolić D (2009) Građansko pravo i životna sredina, in: Nikolić D (ed.) Osnove prava zivotne sredine, 169-192.

17. Salma J (2009) Obligacionopravna zaštita životne sredine: tužba radi otklanjanja izvora opasnosti za nastanak ekološke štete i tužba radi naknade ekološke štete, Zbornik Pravnog fakulteta u Novom Sadu, 2(43), pp. 33-53.

18. Salma M (2014) Preventivna tužba za otklanjanje izvora opasnosti od štete u svetlu održivog razvoja, Zbornik radova Pravnog fakulteta u Novom Sadu, 4(48), pp. 131-145.

19. Šago D (2013) Ekološka tužba kao instrument građanskopravne zaštite okoliša, Zbornik radova Pravnog fakulteta u Splitu, 4(50), pp. 895-915.

20. Vučković M (2018) Građanskopravni aspekt zaštite od prekomernih imisija, doctoral thesis, Niš. 